\title{
Results of Future Physical Therapists' Training for Application of Fitness and Health-Improving Technologies
}

\author{
Burka Olena $^{1^{*}}$, Mazin Vasyl ${ }^{2}$ \\ Zaporizhzhya National Technical University, 64 Zhukovskogo str., Zaporizhzhya, 69063, Ukraine \\ *Corresponding Author: Burka Olena, Zaporizhzhya National Technical University, 64 Zhukovskogo \\ str., Zaporizhzhya, Ukraine
}

\begin{abstract}
The article outlines the results of training of future physical rehabilitation specialists' for application of fitness and health-improving technologies. Results of theoretical analysis of scientific and methodological sources regarding the problem in question are presented. Training process model, fitness and health-improving technologies application readiness forming stages, and diagnostic system are determined and grounded, and pedagogical experiment with regard to proposed innovations efficacy check is outlined.
\end{abstract}

Keywords: physical therapist, fitness and health-improving technologies, training process

\section{INTRODUCTION}

Recently, decrease in life quality and duration of the population, causing deterioration of human body function, promotes an increase in social demand for health state correction using non-medicated means. In the health care system, this function is to be exercised by physical therapists, providing systemic effect on a human body through physical exercises and other means of physical rehabilitation.

Reforming of higher education process, expanding specialists' scope of work in physical rehabilitation necessitates inclusion of new tools for health state correction - fitness and health improvement technologies (FHIT) within rehabilitation process. This tool is a system of organizing human locomotor behavior, providing restoration, balancing and strengthening of functions of a human body.

Introduction of this tool into the health care system and, consequently, the need to improve the training process for specialists, determine our interest in studying and development of a training process for application of fitness and health improvement technologies for future physical therapists.

The theoretical analysis findings have shown that equivalence of national and international definitions of "physical rehabilitation" and "physical therapy" terms [2] serves as a ground for using a basis of a previous specialty for physical therapists training.

A lot of attention has been paid to studying the problem of rehabilitation specialists training. A. Vovkanich and S. Gorodinsky analyzed structure of training programs and disciplines that form theoretical knowledge, practical skills and expertise [3; 5]. A. Vovkanich and Y. Prystupa studied roles and places of physical rehabilitation specialists in the entire health care system [4]. N. Byelikova and Y. Lyannyi characterized distinctive features of foreign students' training etc.

It is clear that quality vocational training is a key to ensure a high level of services provided by physical therapists.

Today, physical therapists' training is based on development of competency models, optimization of training through predominantly practical training, practicing in use of theoretical knowledge during job training, and studying features of the profession and employment, etc. [1].

Despite numerous scientific publications dealing with training of future physical therapists, no study on the preparation for application of fitness and health improvement technologies has been carried out so far. 


\subsection{Purpose and Objectives}

The purpose of the article is to substantiate the model of future physical therapists' training process for application of fitness and health improvement technologies.

In order to ensure the utmost completeness of the study on the chosen topic, let's determine the task of our study:

- to analyze the current state of the problem of future physical therapists' training for application of fitness and health improvement technologies;

- to identify factors of readiness to apply fitness and health improvement technologies;

- to substantiate pedagogical prerequisites for training of future physical therapists for application of FHIT;

- to build a model and determine a diagnostic system for training of future physical therapists to apply FHIT;

- to test effectiveness of the FHIT application readiness model for future physical therapists.

\section{RESULTS}

The theoretical analysis showed that works by V. Ivanochko, M. Ivlev, L. Kostjunin, S. Kroshka, A. Laputin, O. Matlina, S. Yurchuk and others dealt with problems of studying and implementing of FHIT as a means of health correction. Works written by these authors cover a wide population range: from pregnant women and babies to the elderly people [1].

However, in today's situation preparation for the FHIT implementation in professional activity features the following disadvantages:

- readiness to use FHIT is not a training objective;

- training has a purely theoretical basis for readiness formation;

- a narrow range of FHIT in rehabilitation practice in rehabilitation institutions and fitness and health improvement centers.

In order to eliminate existing shortcomings, it is practical to develop and substantiate the process of training for application of FHIT as a whole.

Traditionally, the first step of the training process development is to define the concept of "readiness for application of FHIT". In order to do this, we conducted a survey among experts in the fitness and health improvement field, and by application of factor analysis method to the collected data we obtained a structural model of readiness.

The structural model of future physical therapy specialists' readiness integrates the following components and characteristics: communicative (social competence, compliance with social, ethical and moral norms, pedagogical skills), somatic (knowledge about the structure, functions and conditions of the human body, aspirations maintain health and fitness), personal (responsibility, focus on professional self-realization, ability to engage customers into co-operative training) and fitness and practical (knowledge on the theory and methods of physical education, awareness in modern fitness and health-improving techniques, ability to develop and correct health improvement programs).

Pedagogical conditions are the means ensuring formation of a qualitative level of readiness for application of FHIT. In order to determine the meaning of this component of training process, and, therefore, fulfillment of the third task of our study, we conducted a review of scientific source works.

As a result, it was determined that the process of training of physical rehabilitation specialists has certain characteristic features. Among others, the authors define the following ones: high level of autonomy, domination of practical constituent and stimulation of self-realization ambition.

Theoretical data constitute the basis for assumption that the implementation of future physical therapists training characteristic features for application of FHIT and, consequently, enhancement of 
quality of such training, is possible in case of introduction of the following pedagogical conditions into the educational process:

- stimulating interest in studying of fitness and health improvement technologies through excursions, organization of communication with leading instructors within the educational process;

- formation of the cognitive basis of readiness for application of fitness and health improvement technologies during innovative lectures, work in microgroups, resolution of situational problems, diagrams creation, development of individual and group fitness programs, quick comprehension checks, work with online resources;

- execution of theoretical knowledge in practice in the classroom (business games, mutual learning with consequent video analysis) and quasi-professional (implementation of FHIT in educational practice) activities;

- introduction of a self-control system and expert supervision to control readiness of future physical therapists to apply health improving technologies into their educational process.

In order to provide the learning process providing high level of readiness, we have fulfilled the fourth goal of our study - we created a training model.

According to our plan, this model consists of three parts: standard and target determination, procedure, and results control.

The first part - determination of standards and targets - is a basis of our study. It constitutes background of the training process based on the scientific, methodological and normative principles of professional training of physical rehabilitation specialists, which, in turn, strengthens important component of teaching - pedagogical conditions.

The procedure part serves the author's intention to provide methodological support for the four stages of the training process: preparatory, theoretical, practical and quasi-professional, which aim in formation of theoretical knowledge, practical skills and the ability to execute them in environment close to professional activity.

The third part - control of results - comprises components of readiness, means of their assessment, and five levels of readiness to apply FHIT.

For implementation of the results control part during training process, we have created a diagnostic system determining degree of readiness of future physical therapists to apply FHIT.

The developed readiness degree assessment system integrates the following: criteria and indicators, level features, methods of assessment, qualimetric readiness model.

The criteria for readiness are the following: communicative (featured by "social competence", "observance of social, ethical and moral norms", pedagogical skills), somatic (features: "knowledge of the structure, functions and conditions of the human body", "aspiration for maintenance of health and fitness"), personal (features: "responsibility", "focus on professional self-realization" and "ability to engage customers into co-operative training") and fitness and practical (features: "knowledge of the theory and methods of physical education", "awareness in modern fitness and health-improving techniques", ability to develop and correct health improvement programs).

The methods of readiness assessment are the following: surveys, theoretical knowledge checks, communication and managerial skills technique, method of "Pedagogical situations", expert assessments.

Readiness levels: low, below average, average, above average, high.

The qualimetric model has a tree-type structure; eleven indicators of readiness gradually form a single whole - readiness assessment (in a form of a unit fraction). This assessment tool was chosen because of the need to combine several readiness indicators into one single assessment. It is based on unified standards of diagnostic methods, and is calculated using the definition of $20^{\text {th }}, 40^{\text {th }}, 60^{\text {th }}$, and $80^{\text {th }}$ percentiles. 
In order to assess readiness of future physical therapists to apply FHIT, it is useful to determine relevant index using an Excel-based toolkit, which uses a qualimetric assessment model developed by the author.

Fulfillment of the fifth task of our study - checking effectiveness of the training model - was carried out during the pedagogical experiment.

The experiment lasted for four years (2014 till 2018). 276 students of the "Physical Rehabilitation" specialty took part in it; they were divided into 4 groups: control and experimental at the beginning of the study and control and experimental at the end of it.

Experimental groups (EG) included students of the IV year of "Physical Rehabilitation", the Faculty of Management of Physical Culture and Sports, Zaporizhzhya National Technical University in 2014 and 2018, their number was 70 people. Control groups (CG) were populated with students from Zaporizhzhya National University of the same specialty and year of graduate; total number of participants was 68. According to the level of readiness of students, their material and technical support, staffing and terms of training of the groups were roughly the same.

The composition of the CG and EG groups was not subject to standardization, since our experiment was based on the study of unrelated samples.

The results of assessment of readiness degree for application of FHIT to be compared were the following:

- $\quad$ CG toEG at the beginning of the experiment (2014);

- $\mathrm{CG}$ to EG at the beginning of the experiment (2018)

- $\mathrm{CG}$ at the beginning to $\mathrm{CG}$ at the end of the study;

- $\mathrm{EG}$ at the beginning to $\mathrm{CG}$ at the end of the study.

Training of the CG was carried out according to the standard curricula of higher education institutions. The EG studied under the author's model of future physical therapists' training for application of FHIT.

The differences between training processes in the EG involve introduction of new teaching techniques into the educational process, which provided for formation of eleven signs of readiness for application of FHIT. Innovative training methods were introduced into "Introduction to the specialty", "Biomechanics", "Sports and Pedagogical Improvement", "Theory and technologies of healthimproving and recreational of motion activity" disciplines and into their job training.

In order to process the results of the experiment, we used the method of determination difference in readiness degree in unrelated samples - i. e. the Mann-Whitney criterion.

In particular, while comparing the research data concerning CG and EG it was found out that at the beginning the readiness degree had a statistically significant difference $(p>0.05)$ under no criterion.

Findings of the pedagogical experiment are presented in Table 1.

Table1. Dynamics of future physical therapists' readiness to apply fitness and health-improving technologies in the $E G$ and the $C G$

\begin{tabular}{|c|c|c|c|c|c|c|c|c|}
\hline \multirow[t]{2}{*}{ Group } & \multirow[t]{2}{*}{ Stage } & \multirow{2}{*}{$\begin{array}{l}\text { Statistical } \\
\text { value }\end{array}$} & \multicolumn{5}{|c|}{ Degree } & \multirow{2}{*}{ Total } \\
\hline & & & Low & Below average & Average & Above average & High & \\
\hline \multirow[t]{4}{*}{ CG } & \multirow[t]{2}{*}{ Beginning } & Incidence & 3 & 11 & 28 & 25 & 1 & 68 \\
\hline & & $\%$ per line & $4.41 \%$ & $16.18 \%$ & $41.18 \%$ & $36.76 \%$ & $1.47 \%$ & \\
\hline & \multirow[t]{2}{*}{ End } & Incidence & 3 & 18 & 25 & 21 & 1 & 68 \\
\hline & & $\%$ per line & $4.41 \%$ & $26.47 \%$ & $36.76 \%$ & $30.88 \%$ & $1.47 \%$ & \\
\hline \multirow[t]{4}{*}{ EG } & \multirow[t]{2}{*}{ Beginning } & Incidence & 8 & 16 & 22 & 23 & 1 & 70 \\
\hline & & $\%$ per line & $11.43 \%$ & $22.86 \%$ & $31.43 \%$ & $32.86 \%$ & $1.43 \%$ & \\
\hline & \multirow[t]{2}{*}{ End } & Incidence & 7 & 8 & 10 & 26 & 19 & 70 \\
\hline & & $\%$ per line & $10.00 \%$ & $11.43 \%$ & $14.29 \%$ & $37.14 \%$ & $27.14 \%$ & \\
\hline
\end{tabular}


As Table 1 shows, improvement of the quality of future physical therapists' readiness to use FHIT is observed only in the EG.

Thus, the number of students who had a "low" degree of readiness decreased from $11.43 \%$ to $10 \%$. For the "below average" and "average" degrees, the rates decreased from $22.86 \%$ to $11.43 \%$ and from $31.43 \%$ to $14.29 \%$, respectively. The "above average" degree in the EG was observed at the beginning of the experiment in $32.86 \%$ of students, and at the end of the study, this value reached $37.14 \%$.

Regrettably, at the beginning of the experiment, "high" readiness score was diagnosed only in $1.43 \%$ of the participants of the study (i. e. in one student). However, at the end of the experiment, this value increased to $27.14 \%$ (19 participants).

In CG, the comparison of the metrics dynamics between the data at the beginning and the end of the experiment showed little change.

Thus, the percentage of students with a "low" level was $4.41 \%$. The score of "below average" increased from 16.18 to $41.18 \%$, and on the contrary, the number of participants with "average" and "above average" score has decreased (from $41.18 \%$ to $36.76 \%$ and from $36.76 \%$ to $30.88 \%$, respectively).

Same as the experimental group, the CG showed "high" degree diagnosed only in one student, i. e. in $1.47 \%$. However, unlike the one of the EG, this value showed no change in the CG during training for application of FHIT.

Thus, the statistical processing of the obtained data during the experiment has shown effectiveness of the proposed training process model for future physical therapists for FHIT application. It is supported by the fact that the comparison of the overall readiness score in the EG and the CG using the MannWhitney criterion showed a significant difference $(\mathrm{p}<0.05)$ between the level of group preparation. Also, comparison of data obtained at the beginning and end of the study has shown that there was a significant increase in the level of readiness in the EG, when there were no statistically significant changes in the CG.

\section{CONCLUSION}

Thus, the results of our research show that the developed pedagogical conditions and the model of future physical therapists' readiness to apply FHIT have proved their effectiveness.

Possible areas of further research include development of pedagogical conditions and models for training of future physical therapists to apply FHIT in their professional activities in people with special needs.

\section{REFERENCES}

[1] Burka O. M. (2017) Postanovka problemy pidhotovky reabilitolohiv do vykorystannia fizkulturnoozdorovchykh tekhnolohii [The statement of the problem of preparation of rehabilitation specialists for the use of physical culture and health technologies]. Visnyk Luhanskoho natsionalnoho universytetu imeni Tarasa Shevchenka. Pedahohichni nauky. - Reporter of Luhansk Taras Shevchenko national university. Pedagogical science. 3 (308), 247-254 [in Ukrainian].

[2] Hertsyk A. M. (2009) Do pytannia tlumachennia osnovnykh terminiv haluzi fizychnoi reabilitatsii [On the question of interpretation of key terms associated with physical rehabilitation (continued)]. Biuleten Ukrainskoi asotsiatsii fakhivtsiv fizychnoi reabilitatsii. - Bulletin of Ukrainian Association of Specialists of Physical Rehabilitation. 2, 4-6. Retrieved from http://www.physrehab.org.ua/tl_files/Files/bulletins/ Buleten_02_ua_web.pdf [in Ukrainian]

[3] Horodynskyi S. I. (2015) Rozghliad problemy pidhotovky cuchasnykh reabilitolohiv v Ukraini [Consideration of the problem of training modern rehabilitation specialists in Ukraine]. Molodyi vchenyi. Young scientist. 5, 170-173 [in Ukrainian].

[4] Prystupa Ye. N. (2011) Rol i mistse fakhivtsia z fizychnoi reabilitatsii v systemi okhorony zdorovia naselennia [The role and place of a specialist in physical rehabilitation in the public health system]. Pedahohika, psykholohiia ta medyko-biolohichni problemy fizychnoho vykhovannia $i$ sportu. Pedagogics, psychology, medical-biological problems of physical training and sports. 9, $92-96$ [in Ukrainian]. 
[5] Vovkanych A. S. (2010) Pidhotovka fakhivtsiv z fizychnoi reabilitatsii u konteksti rozvytku osvity u haluzi fizychnoho vykhovannia i sportu [Training of physical rehabilitation specialists in the context of the development of education in the field of physical education and sports]. Kontseptsiia rozvytku haluzi fizychnoho vykhovannia $i$ sportu $v$ Ukraini. - The Concept on development of the field of physical education and sports in Ukraine. 7, 37-42 [in Ukrainian].

\section{AUTHOR'S BIOGRAPHY}

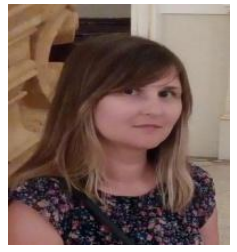

Olena Burka, Senior Lecturer of the Special Education and Rehabilitation Science Department of Zaporizhzhya National Technical University. Obtained master degrees in Physical Rehabilitation and Education. Main field of research focuses on physical therapists` professional training.

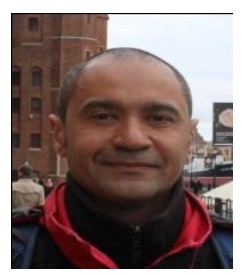

Vasyl Mazin, Doctor of Education, docent, head of Physical Education and Spots Department of Zaporizhzhya National Technical University. Main field of research lies in the sphere of Physical Education and Spots.

Citation: Burka Olena, Mazin Vasyl. “ Results of Future Physical Therapists' Training for Application of Fitness and Health-Improving Technologies". International Journal of Humanities Social Sciences and Education (IJHSSE), vol 5, no. 6, 2018, pp. 1-6. doi: http://dx.doi.org/10.20431/2349-0381.0506001.

Copyright: (C) 2018 Authors. This is an open-access article distributed under the terms of the Creative Commons Attribution License, which permits unrestricted use, distribution, and reproduction in any medium, provided the original author and source are credited. 